\title{
ANALISIS FAKTOR - FAKTOR YANG BERPENGARUH TERHADAP PROFITABILITAS BANK PERKREDITAN RAKYAT DI INDONESIA PADA TAHUN $2013-2017$
}

\author{
Oleh \\ Astohar $^{1)}$, Tri Sumiyanti ${ }^{2)}$ \\ STIE Totalwin Semarang
}

\begin{abstract}
Abstrak
Perbankan berperan dalam perkembangan ekonomi yaitu dalam memacu pertumbuhan perekonomian. Fungsi utama bank adalah sebagai perantara keuangan dari pihak yang memiliki kelebihan dana dengan pihak yang kekurangan dana. Keberadaan sektor perbankan memiliki peranan cukup penting, dimana dalam kehidupan masyarakat sebagian besar melibatkan jasa dari sektor perbankan. Profitabilitas perbankan merupakan rasio untuk mengetetahui kinerja keuangan dari perbankan. Hasil penelitian dari dari Ali dan Laksono (2017) masih menarik untuk dikembangkan baik variabelnya maupun obyek penelitiannya.

Penelitian ini mengambil obyek pada Bank Perkreditan Rakyat di Indonesia yang mempunyai Aset di atas 500 milyar. Populasi dalam penelitian ini adalah seluruh perusahaan dalam seluruh perbankan yang berkategori Bank Perkreditan Rakyat di Indonesia2013 - 2017. Populasi dalam penelitian ini adalah sebanyak 1.637 perbankan yang tercatat sampai dengan tahun 2018. Pemilihan sampel dilakukan dengan menggunakan metode purposive sampling (pertimbangan tertentu) yaitu dengan pertimbangan yaitu BPR dengan asset diatas 500 milyar selama 5 tahun terakhir. Atas dasar pertimbangan tersebut menghasilkan sampel 8 Bank Perkreditan Rakyat

Hasil penelitian menunjukkan Capital adequacy ratio (CAR) Bank Perkreditan Rakyat di Indonesia mempunyai pengaruh negatif dan signifikan terhadap profitabilitas bank ( $H_{1}$ diterima).Non Performing Loan (NPL) Bank Perkreditan Rakyat di Indonesia mempunyai pengaruh negatif dan tidak signifikan terhadap profitabilitas bank ( $\mathrm{H}_{2}$ ditolak). Loan to deposit ratio (LDR) Bank Perkreditan Rakyat di Indonesia mempunyai pengaruh positif dan signifikan terhadap profitabilitas bank ( $\mathrm{H}_{2}$ diterima). Biaya Operasional terhadap Pendapatan Operasional (BOPO) Bank Perkreditan Rakyat di Indonesia terbukti mempunyai pengaruh negatif dan signifikan terhadap profitabilitas bank ( $H_{4}$ diterima). Net Interest Margni (NIM) Bank Perkreditan Rakyat di Indonesia mempunyai pengaruh negative dan signifikan terhadap profitabilitas bank $\left(\mathrm{H}_{5}\right.$ diterima).
\end{abstract}

Kata Kunci : capital adequacy ratio (CAR), non performing loan (NPL), loan to deposit ratio $(L D R)$, biaya operaional dan pendapatan operasional (BOPO), net interest margin (NIM)dan return on assets (ROA) 


\section{PENDAHULUAN}

Perbankan berperan untuk mendorong perkembangan ekonomi dan untuk memacu pertumbuhan perekonomian di negara. Hal ini disebabkan perbankan mempunyai fungsi utama sebagai perantara keuangan (financial intermediary) dari pihak yang memiliki kelebihan dana (surplus) dengan pihak yang kekurangan dana (defisit) (Nusantara, 2009). Perbankan merupakan lembaga keuangan yang memiliki peranan dalam sistem keuangan di Indonesia. Keberadaan sektor perbankan memiliki peranan cukup penting, dimana dalam kehidupan masyarakat sebagian besar melibatkan jasa dari sektor perbankan (Putrianingsih dan Yulianto, 2016).

Kepercayaan selalu dikedepankan untuk menarik sebanyak mungkin nasabah juga para investor. Hal ini dimaksudkan untuk memperbesar dananya dan juga memperbesar pemberian kredit dan jasanya. Peran bank menjadi strategis dengan tetap menjaga kesehatan dan stabilitas perbankan (Veithzal, dkk,2007). Perbankan yang sehat merupakan kebutuhan suatu perekonomian yang ingin tumbuh dan berkembang dengan baik. Fungsi intermediasi perbankan setelah terjadinya krisis perbankan di Indonesia telah mengakibatkan lambannya kegiatan investasi dan pertumbuhan ekonomi (Defri, 2012).

Industri perbankan merupakan industri yang syarat dengan risiko, karena melibatkan pengelolaan uang masyarakat dan diputar dalam bentuk berbagai investasi, seperti pemberian kredit, pembelian surat-surat berharga dan penanaman dana lainnya (Ghozali, 2007). Kondisi perbankan di Indonesia selama ini merupakan periode yang banyak dinamika bagi industri perbankan nasional. Ditengah beratnya tantangan yang dihadapi, bank pada umumnya mampu mempertahankan kinerja positif. Profitabilitas, likuiditas dan solvabilitas bank stabil pada tingkat yang memadai. Fungsi intermediasi masih kendala akibat perubahan kondisi perekonomian yang kurang menguntungkan (Muslem dan Chabachib, 2016)

Perbankan di Indonesia pada saat ini memasuki masa persaingan yang sangat kompetitif. Hal ini disebabkan banyaknya bank yang beroperasi di Indonesia baik yang beroperasi secara lokal maupun yang beroperasi berskala internasional. Semakin kompetitifnya persaingan di dunia perbankan maka bank-bank mulai meningkatkan keunggulan kompotetitifnya untuk memberikan layanan yang terbaik kepada para 
nasabahnya melalui berbagai macam produk perbankan seperti produk dana, produk pinjaman atau produk jasa lainnya (Rahmani, 2017).

Menurut Latifah dkk (2012) kinerja keuangan perbankan dapat diketahui dengan melihat rasio profitabilitas. Faktor-faktor yang mempengaruhi profitabilitas bank dapat bersumber dari berbagai kinerja profitabilitas yang ditunjukkan beberapa indikator. Menurut Bank Indonesia rasio profitabilitas yang penting bagi bank adalah (ROA). Hal ini didukung oleh Astohar (2016) yang menunjukkan bahwa return on asset (ROA) digunakan untuk mengukur profitabilitas bank, karena Bank Indonesia sebagai pembina dan pengawas perbankan lebih mengutamakan nilai profitabilitas suatu bank yang diukur dengan aset yang dananya sebagian besar dari dana simpanan masyarakat. Semakin besar ROA suatu bank, semakin besar pula tingkat keuntungan yang dicapai bank, dan semakin baik posisi bank tersebut dari segi penggunaan asset.

Return on Asset (ROA) memfokuskan kemampuan perusahaan untuk memperoleh earning dalam operasi perusahaan, sedangkan Return On Equity (ROE) hanya mengukur return yang diperoleh dari investasi pemilik perusahaan dalam bisnis tersebut (Marwadi, 2005), sehingga dalam penelitian ini ROA digunakan sebagai ukuran kinerja perbankan. ROA merupakan rasio antara laba sebelum pajak terhadap total asset. semakin besar ROA menunjukkan kinerja semakin baik, karena tingkat pengembalian (return) semakin besar. Apabila ROA meningkat, berarti profitabilitas perusahaan meningkat, sehingga dampak akhirnya adalah peningkatan profitabilitas yang dinikmati oleh pemegang saham (Husnan, 2012).

Bank yang baik ditandai dengan tingkat tingkat profitabilitas yang tinggi, mampu membagikan deviden dengan baik, prospek usaha yang selalu berkembang, dan dapat memenuhi ketentuan prudential banking regulation dengan baik (Kuncoro dan Suhardjono, 2005 dalam Khoirunisa, 2016). Return on Asset (ROA) yang positif menunjukkan bahwa dari total aktiva yang dipergunakan untuk beroperasi, perusahaan mampu memberikan laba bagi perusahaan. Sebaliknya apabila yang negatif menunjukkan bahwa dari total aktiva yang dipergunakan, perusahaan mendapatkan kerugian. Jadi jika suatu perusahaan mempunyai ROA yang tinggi maka perusahaan tersebut berpeluang besar dalam meningkatkan pertumbuhan. Tetapi jika total aktiva 
yang digunakan perusahaan tidak memberikan laba maka perusahaan akan mengalami kerugian dan akan menghambat pertumbuhan (Simanjutak, 2016).

Return on asset (ROA) dikatakan penting bagi bank karena untuk mengukur efektivitas perusahaan didalam menghasilkan keuntungan dengan memanfaatkan aktiva yang dimilikinya. Return on asset (ROA) merupakan rasio antara laba sesudah pajak tehadap total asset. Banyak fakor yang mempengaruhi profitabilitas dimana profitabilitas merupakan kemampuan bank untuk menghasilkan laba secara efektif dan efisien (Ali dan Laksono, 2017). Faktor - faktor tersebut seperti non performing loan (NPL), loan to deposit ratio (LDR), biaya operasional dan pendapatan operasional (BOPO) serta net interest margin (NIM) (Ali dan Laksono, 2017).

Permasalahan dalam penelitian ini adalah menyempurnakan penelitian dari Ali dan Laksono (2017) dengan menambah variable capital adequacy ratio (CAR) juga mempunyai dampak terhadap profitabilitas bank (Khoirunisa dkk, 2016). Variable capital adequacy ratio (CAR) dipilih karena variable ini masih terjadi perdebatan dalam mempengaruhi profitabilitas. Menurut Bernadin (2016) rasio kecukupan modal berpengaruh positif terhadap profitabilitas yang didukung oleh Rahmani (2017) peningkatan capital adequacy ratio $(C A R)$ dapat meningkatkan profitabilitas. Hasil yang berbeda dari (Candra, 2013) yang mana peningkatan capital adequacy ratio (CAR) justru menurunkan profitabilitas perbankan.

\section{PAPARAN TEORITIS}

\section{Anticipated Income Theory}

Dalam teori antisipasi pendapatan, bank layak memberikan kredit jangka panjang yang pelunasannya dijadwalkan sesuai dengan ketetapan waktu. Jadwal pembayaran dalam bentuk angsuran pokok dan bunga akan menjadi supplier arus kas secara teratur dan akhirnya kebutuhan likuiditas pun terpenuhi. Teori antisipasi pendapatan mengutamakan likuiditas, sehingga bank dapat mengantisipasi kewajiban sesegera mungkin dan memprediksikan alat-alat lancar yang akan masuk. Teori ini mendorong bank untuk memperlakukan pinjaman jangka panjang sebagai potensi sumber likuiditas (Salmiana, 2018).

Teori antisipasi pendapatan dalam hal penelitian ini menjelaskan bahwa kegagalan penyaluran dana-dana repatriasi dari kebijakan tax amnesty atau pengampunan pajak ke dalam aset produktif akan memicu naiknya inflasi dan kredit 
macet atau non performing loan di industri perbankan. Semakin tinggi tingkat non performing loan maka semakin besar pula risiko kredit yang ditanggung oleh pihak bank. Akibat tingginya non performing loan perbankan akan lebih berhati - hati (selektif) dalam menyalurkan kredit.

Teori antisipasi pendapatan ini juga menjelaskan capital adequacy ratio sebagai salah satu faktor rasio permodalan perbankan. Capital adequacy ratio adalah rasio yang memperlihatkan seberapa jauh seluruh aktiva bank yang mengandung risiko (kredit, penyertaan, surat berharga, tagihan pada bank lain) ikut dibiayai dari dana modal sendiri bank disamping memperoleh dana-dana dari sumber-sumber diluar bank, seperti dana masyarakat, pinjaman, dan sebagainya.

\section{Profitabilitas}

Profitabilitas atau disebut dengan rentabilitas adalah kemampuan suatu perusahaan untuk menghasilkan laba selama periode tertentu. Dimana rentabilitas perusahaan menunjukkan perbandingan antara laba dengan aktiva atau modal yang menghasilkan laba tersebut (Bambang, 2001 dalam Defri, 2012). Menurut Slamet (2001dalam Defri, 2012) profitabilitas ialah keefektifan operasiserta derajat keuangan suatu perusahaan. Profitabilitas bank merupakan suatu kemampuan bank dalam menghasilkan laba dengan memanfaatkan aktiva yang dimiliki dakan dalam suatu periode (Riyadi, 2006, dalam Astohar, 2016).

Profitabilitas (profitability) atau diproksi dengan ROA adalah kemampuan suatu bank dalam memperoleh laba. menurut Bank Indonesia, (ROA) merupakan perbandingan antara laba setelah pajak dengan total asset dalam satu periode. ROA digunakan untuk mengukur kemampuan manajemen bank dalam memperoleh keuntungan (laba sebelum pajak) yang dihasilkan dari rata-rata total aset bank yang bersangkutan. Semakin besar ROA, semakin besar pula keuntungan yang dicapai perbankan sehingga kemungkinan suatu bank dalam kondisi bermasalah semakin kecil. Laba sebelum pajak adalah laba bersih dari kegiatan operasional sebelum pajak. Sedangkan rata-rata total aset adalah volume usaha atau aktiva (Luciana dan Winni, 2005).

Return on Asset (ROA) adalah rasio perbandingan antara laba setelah pajak dengan total aktiva (total asset) yang digunakan untuk mengukur kemampuan perusahaan 
dalam menghasilkan laba atas aktiva (total asset) yang dipergunakan dalam periode tertentu (Fauziah, 2011). Apabila ROA perusahaan terjadi peningkatan dari tahun ke tahun, maka bisa dikatakan perusahaan semakin efisien dalam mengelola bisnisnya. Semakin besar ROA suatu bank, semakin besar pula tingkat keuntungan yang dicapai bank dan semakin baik posisi bank tersebut dari segi penggunaan asset (Dendawijaya, 2009). Profitabilitas dari bank tidak hanya penting bagi pemiliknya, tetapi juga bagi golongan-golongan lain di dalam masyarakat. Bila bank berhasil mengumpulkan cadangan dengan memperbesar modal, akan meminjamkan yang lebih besar karena tingkat kepercayaan atau kridibilitas meningkat (Simoragkir, 2004).

Return on asset (ROA) adalah perbandingan antara laba bank dengan total aktiva (Dendawijaya, 2005). ROA menunjukkan kemampuan manajemen bank dalam menghasilkan income dari pengelolaan aset yang dimiliki (Kuncoro dan Suhardjono, 2011). Semakin besar ROA maka kondisi bank akan semakin baik. (ROA) atau hasil pengembalian atas aset merupakan rasio yang menunjukkan hasil atas penggunaan aset perusahaan dalam menciptakana laba bersih, dengan kata lain rasio ini digunakan untuk mengukur seberapa besar jumlah laba bersih yang akan dihasilkan dari setiap rupiah dana yang tertanam dalam total aset (Hery 2015).

\section{Capital Adequacy Ratio}

Capital adequacy ratio merupakan rasio kinerja bank untuk mengukur kecukupan modal yang dimiliki bank untuk menunjang aktiva yang mengandung atau menghasilkan resiko. CAR menjadi rasio kecukupan modal yang berfungsi menampung risiko kerugian yang kemungkinan dihadapi oleh bank. Semakin tinggi CAR, maka semakin baik kemampuan bank tersebut untuk menanggung risiko dari setiap kredit / aktiva produktif yang berisiko tertimbang (Rahmani, 2017). Capital adequacy ratio $(C A R)$ adalah rasio kinerja bank untuk mengukur kecukupan modal yang dimilki bank untuk menunjang aktiva yang mengandung atau mengahasilkan resiko, misalnya kredit yang diberikan (Dendawijaya, 2005).

Semakin tinggi resiko rasio CAR maka semakin baik kondisi suatu bank dan jika nilai CAR tinggi berarti bank tersebut mampu membiayai kegiatan operasinya. Tingginya CAR mengindikasikan bahwa bank tersebut mampu membiayai kegiatan operasional dan memberikan kontribusi yang cukup besar bagi profitabilitas (Kuncoro et al. 2002). Hal berbeda ditunjukkan oleh Khoirunisa (2016) yang mana hasil 
penelitian menunjukan bahwa capital adequacy ratio (CAR) tidak berdampak terhadap profitabilitas bank, yaitu kenaikan dari CAR tidak serta merta meningkatkan profitabilitas bank. Lebih lanjut hasil penelitian dari Candra (2013) menunjukkan bahwa peningkatan capital adequacy ratio $(C A R)$ justru menurunkan profitabilitas perbankan. Berdasarkan argument peneliti diatas dapat ditarik hipotesis 1 sebagai berikut :

$\mathrm{H}_{1}$ : capital adequacy ratio modal berpengaruh negative dan signifikan terhadap profitabilitas Bank Perkreditan Rakyat

\section{Non Performing Loan (NPL)}

Non performing loan (NPL) menunjukkan kemampuan manajemen bank dalam mengelola kredit bermasalah yang diberikan oleh bank. Apabila suatu bank kondisi NPL tinggi maka akan memperbesar biaya lainnya, sehingga berpotensi terhadap kerugian bank (Mawardi, 2005). Semakin tinggi rasio NPL maka semakin buruk kualitas kredit yang menyebabkan jumlah kredit bermasalah semakin besar sehingga dapat menyebabkan kemungkinan suatu bank dalam kondisi bermasalah semakin besar. Setelah kredit diberikan, bank wajib melakukan pemantauan terhadap penggunaan kredit serta kemampuan dan kepatuhan debitur dalam memenuhi kewajiban.

Non perfoming loan $(N P L)$ yang tinggi akan memperbesar biaya, sehingga berpotensi terhadap kerugian bank. Semakin tinggi rasio ini maka akan semakin buruk kualitas kredit bank yang menyebabkan jumlah kredit bermasalah semakin besar (Samsara, 2016). Maka dalam hal ini semakin tinggi rasio NPL maka semakin rendah profitabilitas suatu bank. Lebih lanjut Muslem dan Chabachib (2016) serta Aprilya (2017) yang memberikan hasil bahwa non performing loan (NPL) berpengaruh negative terhadap profitbilitas. Berdasarkan argument tersebut dapat dirumuskan hipotesis kedua $\left(\mathrm{H}_{2}\right)$ sebagai berikut :

$\mathrm{H}_{2}$ : non performing loan mempunyai pengaruh yang negative dan signifikan terhadap return on asset (ROA) Bank Perkreditan Rakyat

\section{Loan To Deposit Ratio (LDR)}

Loan to deposit ratio (LDR) adalah perbandingan antara kredit yang diberikan dengan dana pihak ketiga (giro, tabungan, deposito, dan kewajiban jangka pendek 
lainnya). LDR ini menjadi salah satu tolok ukur likuiditas bank yang berjangka waktu agak panjang. Semakin tinggi LDR menunjukkan semakin jelek kondisi likuiditas bank,

karena penempatan pada kredit juga dibiayai dari dana pihak ketiga yang sewaktuwaktu ditarik (Simanjutak, 2016). Loan Deposit Ratio (LDR) yaitu menunjukkan kemampuan suatu bank di dalam menyediakan dana kepada debiturnya dengan modal yang dimiliki oleh bank maupun dana yang dapat dikumpulkan oleh masyarakat (Achmad, 2003)

Peningkatan loan to deposit ratio (LDR) menunjukkan kurangnya efektifitas bank dalam menyalurkan kredit sehingga hilangnya kesempatan bank untuk memperoleh laba (Sudarmawati dan Pramono (2017). Hal ini menunjukkan bahwa loan to deposit ratio yang tinggi menunjukkan kredit yang diberikan kepada masyarkaat atau nasabah adalah lebih besar dari dana pihak ketiga yang diterima, hal ini berdampak pada kemungkinan peningkatan risiko dan dampaknya adalah justru akan menurunkan profitabilitas bank (Ali dan Laksono, 2017). Berdasarkan argument tersebut dapat dirumuskan hipotesis kedua $\left(\mathrm{H}_{3}\right)$ sebagai berikut :

$\mathrm{H}_{3}$ : loan to deposit ratio (LDR) mempunyai pengaruh yang negative dan signifikan terhadap return on asset (ROA)Bank Perkreditan Rakyat

\section{Pengaruh Biaya Operasional dan Pendapatan Operasional (BOPO)}

Biaya operasional digunakan untuk mengukur tingkat efisien dan kemampuan bank dalam melakukan kegiatan operasionalnya. Biaya operasional merupakan biaya yang dikeluarkan oleh bank dalam rangka menjalankan aktivitas usaha pokoknya (seperti biaya bunga, biaya tenaga kerja, biaya pemasaran dan biaya operasi lainnya). Pendapatan operasional merupakan pendapatan utama bank, yaitu pendapatan bunga yang diperoleh dari penempatan dana dalam bentuk kredit dan pendapatan operasi lainnya. Semakin kecil rasio ini berarti semakin efisien biaya operasional yang dikeluarkan bank yang bersangkutan sehingga kemungkinan suatu bank dalam kondisi bermasalah semakin kecil (Sudamawati dan Pramono, 2017).

Hasil penelitian dari Defri (2012) menunjukkan bahwa biaya operasional dan pendapatan operasional (BOPO) mempunyai pengaruh yang negative terhadap profitabilitas. Hal ini menunjukkan bahwa tingginya biaya operasional akan berdampak pada turunnya pendapatan, sehingga menurunkan stabilitas perbankan (Martindas dkk, 2013). Hal yang sama ditemukan oleh Khoirunisa (2016) serta Ali dan Laksono (2017) 
bahwa variabel efisiensi operasi yang diproksikan dengan BOPO berpengaruh negatif terhadap kinerja perbankan yang diproksikan dengan Return on Assets (ROA). Berdasarkan argument tersebut dapat dirumuskan hipotesis kedua $\left(\mathrm{H}_{4}\right)$ sebagai berikut:

$\mathrm{H}_{4}$ : BOPO mempunyai pengaruh yang negative dan signifikan terhadap return on asset (ROA) Bank Perkreditan Rakyat

\section{Net Income Margin (NIM)}

Net Income Margin (NIM) merupakan rasio yang menunjukkan kemampuan manajemen bank dalam mengelola aktiva produktifnya untuk menghasilkan pendapatan bunga bersih. Pendapatan bunga bersih diperoleh dari pemberian kredit atau pinjaman, sementara bank memiliki kewajiban beban bunga kepada deposan. Semakin besar rasio ini maka meningkatkan pendapatan bunga atas aktiva produktif yang dikelola bank sehingga kemungkinan suatu bank dalam kondisi bermasalah semakin kecil. Sehingga dapat disimpulkan bahwa semakin besar perubahan Net Income Margin (NIM) suatu bank, maka semakin besar pula profitabilitas bank tersebut, yang berarti kinerja keuangan tersebut semakin meningkat (Sudarmawanti dan Pramono, 2017).

Semakin besar rasio ini maka akan meningkatkan pendapatan bunga atas aktiva produktif yang dikelola bank, sehingga kemungkinan suatu bank dalam kondisi bermasalah semakin kecil dan kinerja perbankan tersebut akan semakin baik (Almilia dan Herdiningtyas, 2005). Lebih lanjut hasil penelitian dari Ali dan Laksono (2017) yang menunjukkan bahwa semakin tinggi net interest margin (NIM) akan berdampak pada peningkatan profitabilitas perbankan yang diproksi dengan return on asset (ROA). Berdasarkan argument tersebut dapat dirumuskan hipotesis kedua $\left(\mathrm{H}_{5}\right)$ sebagai berikut:

$\mathrm{H}_{5}$ : net interest margin (NIM) mempunyai pengaruh yang positif dan signifikan terhadap return on asset (ROA) Bank Perkreditan Rakyat 


\section{Kerangka Pikir}

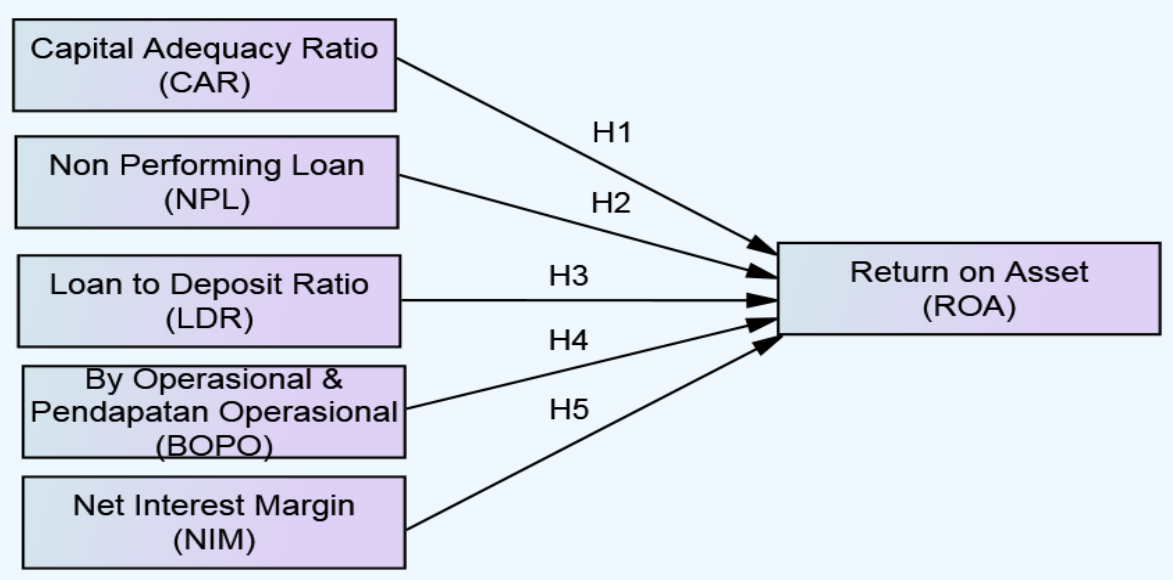

Kerangka pikir dalam penelitian ini adalah sebagai berikut :

\section{Gambar 1 Kerangka Pikir Penelitian}

\section{METODE PENELITIAN}

\section{Definisi Konsep dan Operasional Variabel}

1. ROA (Profitabilitas Bank Perkreditan Rakyat)

Return on asset (ROA) sebagai salah satu pengukur profitabilitas bank karena Bank Indonesia sebagai pemegang regulasi bank lebih mengutamakan nilai profitabilitas suatu bank, yang diukur sebagai berikut (Sartono, 2001):

$$
\text { ROA }=\frac{\text { Laba Sebelum Pajak }}{\text { Total Aset }} \times 100 \% \ldots
$$

2. Capital Adequacy Ratio (CAR)

Capital Adequacy Ratio (CAR) merupakan rasio dari kecukupan modal bank dalam mengukurnya dengan membandingkan antara jumlah modal bank dibandingkan dengan total aktiva tertimbang menurut risiko (ATMR), yang diukur sebagai berikut : (Muhammad, 2006).

$$
\left.\mathrm{CAR}=\frac{\text { Modal }}{\text { ATMR }} \times 100 \%\right)
$$

3. Loan to deposit ratio $(L D R)$

Menurut Dendawijaya (2005) loan to deposit ratio (LDR) menyatakan seberapa jauh kemampuan bank dalam membayar kembali penarikan dana yang dilakukan deposan dengan mengandalkan kredit yang diberikan sebagai sumber likuiditasnya. Berdasarkan SE Bank Indonesia no 12/11/DPNP/2010 : 


$$
\text { LDR }=\frac{\text { Pembiayaan }}{\text { Total Dana Pihak Ketiga }+ \text { modal Inti }} \times 100 \%
$$

4. Non Performing Loan (NPL)

Non Performing loan (NPL) merupakan tingkat dari pengembalian pembiayaan atau kredit atau merupakan tingkat kredit macet pada perbankan, dengan rumus sebagai berikut : (Muhammad, 2006):

$$
\text { NPL }=\frac{\text { Pembiayaantidaklancar }}{\text { Total pembiayaan }} \times 100 \%
$$

5. Beban Operasional terhadap Pendapatan Operasional (BOPO)

Rasio beban operasional terhadap pendapatan operasional atau lebih dikenal dengan istilah (BOPO) merupakan perbandingan dari beban operasional dengan diperbandingkan dengan pendapatan operasionalnya, dengan rumus sebagai berikut.

$$
\text { BOPO }=\frac{\text { Beban Operasional }}{\text { Pendapatan Operasional }} \times 100 \%
$$

6. Net Interest Margin (NIM)

NIM digunakan untuk mengukur kemampuan bank dalam menghasilkan pendapatan dari bunga dengan melihat kinerja bank dalam menyalurkan kredit, yang diukkur dengan rumus sebagai berikut : (Prima, dkk 2015)

$\mathrm{NIM}=\frac{\text { Pendapatan Bunga Bersih }}{\text { Aktiva Produktif }} \times 100 \%$

\section{Populasi dan Sampel}

Populasi dalam penelitian ini adalah seluruh perusahaan dalam seluruh perbankan yang berkategori Bank Perkreditan Rakyat di Indonesia2013 - 2017. Populasi dalam penelitian ini adalah sebanyak 1.637 perbankan yang tercatat sampai dengan tahun 2018. Pemilihan sampel dilakukan dengan menggunakan metode purposive sampling (pertimbangan tertentu) yaitu dengan pertimbangan yaitu BPR dengan asset diatas 500 milyar selama 5 tahun terakhir. Atas dasar pertimbangan tersebut menghasilkan sampel 8 Bank Perkreditan Rakyat, yaitu BPR Modern Express, BPR Palu Lokadana Utama, BPR Eka Bumi Arta, BPR Irian Sentosa, BPR Jatim, BPR Hasa Mitra, BPR Surya Yudhakencana dan BPR Utomo Manunggal 
Sejahtera. Pengumpulan data menggunakan panel, sehingga selama 5 tahun periode penelitian jumlah observasi sebanyak 8 perusahaan dan 40 observasi.

\section{Jenis dan Metode Pengumpulan Data}

Jenis data yang digunakan dalam penelitian ini adalah data kuantitatif berupa laporan keuangan publikasi tahunan yang diterbitkan oleh Bank Indonesia yang diperoleh dari WEB OJK dari periode tahun 2013 sampai tahun 2017. Sumber data yang digunakan ini diperoleh melalui penelusuran dari media internet dari www. ojk.go.id.Metode pengumpulan data yang digunakan yaitu melalui studi pustaka dari direktori perusahaan go publik dan situs resmi tiap perusahaan.idx.go.id. serta situs - situr resmi lainnya yang dijadikan sampel.

\section{Alat Analisis Data \\ Uji Persamaan Regresi Ganda}

Analisis regresi linier berganda adalah pengaruh secara linier antara dua atau lebih variabel independen dengan satu variabel dependen, yaitu pengaruh dari capital adequacy ratio $(C A R)$, loan to deposit ratio $(L D R)$, non performing loan (NPL)dan biaya operasional terhadap pendapatan operasional (BOPO) serta net interest margin (NIM) terhadap Return on Asset (ROA). Sebelum melakukan estimasi yang tidak biasa dengan analisis regresi, perlu dilakukan uji t dan uji Fit data yaitu pengujian antar variabel bebas supaya tidak terjadi multikolinieritas, heteroskedastisitas, normalitas, dan autokorelasi (Astohar, 2013).

Persamaan regresi pada penelitian ini terdapat dua model. yaitu sebagai berikut:

$Y=a+b_{1} X_{1}+b_{2} X_{2}+b_{3} X_{3}+b_{4} X_{4}+b_{5} X_{5}$

Dimana :

$\mathrm{Y}: \mathrm{ROA}$

$\mathrm{X}_{1}: \mathrm{CAR}$

$\mathrm{X}_{2}: \mathrm{NPL}$

$\mathrm{X}_{3}: \mathrm{LDR}$

$\mathrm{X}_{4}: \mathrm{BOPO}$

$\mathrm{X}_{5}: \mathrm{NIM}$ 


\section{Uji Koefisien Determinasi}

Koefisien determinan pada penelitian ini digunakan untuk melihat berapa persen dari variasi variabel terikat dijelaskan variabel bebas. Pada penelitian ini koefisien determinasi adalah mengetahui seberapa besar variasi profitabilitas bank perkreditan rakyat (ROA) dapat diterangkan oleh variasi dari capital adequacy ratio $(C A R)$, loan to deposit ratio $(L D R)$, non performing loan $(N P L)$ dan biaya operasional terhadap pendapatan operasional (BOPO) serta net interest margin (NIM). Nilai determinasi yang digunakan pada penelitian ini adalah nilai adjusted $R^{2}$. Digunakannya nilai tersebut karena nilai adjusted $R^{2}$ pada saat mengevaluasi model regresi dapat naik atau turun apabila satu variabel independen ditambahkan ke dalam model (Ghozali, 2013).

\section{HASIL DAN PEMBAHASAN}

\section{Analisis Deskriptif}

Pada variabelprofitabilitas Bank Perkreditan Rakyat ( $R O A$ ) yang rata-ratanya adalah sebesar 4,58 \%. Berdasarkan rata - rata, Bank Perkreditan Rakyat masuk dalam kategori yang sehat, hal ini ditandai dengan rata - rata profitabilitas Bank Perkreditan Rakyat sudah diatas dikisaran 1,5 \% (Ketentuan Bank Indonesia >1,5 \%). Berdasarkan data yang diperoleh profitabilitas Bank Perkreditan Rakyat (ROA) terendah pada periode penelitian yaitu sebesar 1,61\% yaitu pada BPR Jatim pada tahun 2015. Rasio profitabilitas Bank Perkreditan Rakyat (ROA) tertinggi adalah pada Bank BPR Irian Sentosa pada tahun 2013 yaitu sebesar 8,57 \%.

Pada variabel capital adequacy ratio (CAR) ini menunjukkan bahwa berdasarkan rata - rata Bank Perkreditan Rakyat masuk dalam kategori yang sehat, hal ini ditandai dengan rata - rata capital adequacy ratio (CAR) masih dikisaran 23,57 \% (Ketentuan Bank Indonesia > $8 \%$ ). Capital adequacy ratio $(C A R)$ terendah pada periode penelitian yaitu sebesar $11,5 \%$ yaitu pada BPR Lokadana Utama pada tahun 2016. Rasio capital adequacy ratio (CAR) tertinggi adalah pada BPR Utomo Manunggal Sejahtera pada tahun 2014 yaitu sebesar 53,06.

Pada variabel non performing loan (NPL) ini menunjukkan bahwa berdasarkan rata - rata Bank Perkreditan Rakyat masuk dalam kategori yang sehat, hal ini ditandai dengan rata - rata non performing loan (NPL) masih dikisaran 0,82\% 
(Ketentuan Bank Indonesia < $5 \%$ ). Berdasarkan data yang diperoleh non performing loan $(N P L)$ terendah pada periode penelitian yaitu sebesar $0,001 \%$ yaitu pada BPR Irian Sentosa pada tahun 2013. Rasio non performing loan (NPL) tertinggi adalah pada BPR Jatim pada tahun 2016 yaitu sebesar 5,09\%.

Pada variabel loan to deposit ratio $(L D R)$ ini menunjukkan bahwa berdasarkan rata - rata Bank Perkreditan Rakyat masuk dalam kategori yang sehat, hal ini ditandai dengan rata - rata loanto deposit ratio $(L D R)$ masih dikisaran 86,62\% (Ketentuan Bank Indonesia 85 \% sampai dengan $110 \%$ ). Loan to deposit ratio (LDR) yang paling rendah pada penelitian yaitu sebesar 73,96 \% adalah pada BPR Jatim pada tahun 2015. Rasio loan to deposit ratio (LDR) yang tertinggi adalah pada BPR Palu Lokadana Utama pada tahun 2015 yaitu sebesar 95,74\%.

Pada variabel rasio beban operasional dibanding dengan pendapatan operasional $(B O P O)$ ini menunjukkan bahwa berdasarkan rata - rata Bank Perkreditan Rakyat masuk dalam kategori yang sehat, hal ini ditandai dengan rata - rata BOPO masih dikisaran 73,52\% (Ketentuan Bank Indonesia < $100 \%$ ). Berdasarkan deskriptif data yang didapatkan BOPO terendah pada selama periode penelitian adalah sebesar $58,89 \%$ pada BPR Palu Lokadana Utama pada tahun 2013. Rasio BOPO tertinggi adalah pada BPR Jatim pada tahun 2015 yaitu sebesar 91,55 \%.

Pada variabel rasio net interest margin (NIM) ini menunjukkan bahwa berdasarkan rata - rata Bank Perkreditan Rakyat masuk dalam kategori yang sehat, hal ini ditandai dengan rata - rata NIM masih dikisaran 8,26\% (Ketentuan Bank Indonesia $>1,5 \%)$. Berdasarkan deskriptif data yang didapatkan net interest margin (NIM)terendah pada selama periode penelitian adalah sebesar 4,75\% pada BPR Hasa Mitra pada tahun 2014. Rasio net interest margin (NIM) tertinggi adalah pada BPR Irian Sentosa pada tahun 2013 yaitu sebesar 61,01\%.

\section{Uji Normalitas dan Penyimpangan Asumsi Klasik}

Pada awalnya terdapat 2 observasi terjadi outlier, yaitu pada BPR Modern Express pada tahun 2013 dan 2014. Sehingga data tersebut direkomendasikan untuk dikeluarkan dari data penelitian. Berdasarkan print out grafik di atas, terlihat titiktitiknya pada grafik nampak menyebar menjauh atau tidak berada disekitar pada garis diagonal, serta penyebaran titik - titiknya tidak mengikuti garis diagonal. Selain pada grafik histogram yang menunjukkan data tersebar tidak mendekati garis normalitas. 
Berdasarkan uji Kolmogorov Smirnov sebesar 0,987 yang mana nilai signifikansi tersebut lebih besar dari nilai signifikansi yang telah ditentukan yaitu 0,05. Berdasarkan data tersebut dapat dijelaskan bahwa model regresi telah terdistribusi secara normal.

Hasil pengujian penyimpangan asumsi klasik menunjukkan bahwa model tidak terjadi penyimpangan multikolinearitas yang ditandai dengan nilai VIF dibawah 10 dan nilai tolerance yaitu : 1,$721 ; 1,595 ; 2,431 ; 2,098$ dan 1,527 dan nilai tolerance diatas 0,1 yaitu 0,$581 ; 0,627 ; 0,411 ; 0,477$ dan 0,655 . Grafik scatterplot tidak membentuk pola yang khusus atau jelas, hal ini menunjukkan data tidak terjadi penyimpangan heteroskedastisitas. Nilai durbin Watson sebesar 1,959 yang mana nilai tersebut berada pada interval 1,864 sampai dengan 2,136.

Hasil perhitungan anova didapatkan nilai $\mathrm{F}$ hitungnya sebesar 61,303 untuk nilai probabilitas adalah 0,000 . Hasil ini dikatakan bahwa permodelan yaitu variabel bebas yang berupa CAR, NPL, LDR, BOPO dan NIM secara bersama - sama (simultan) mempunyai pengaruh signifikan terhadap profitabilitas pada Bank Perkreditan Rakyat, atau model yang dibanguntidak memenuhi kriteria fit.

\section{Analisis Regresi Linier Berganda}

Berdasarkan hasil print out spss dapat disajikan persamaan sebagai berikut $\mathrm{Y}=27,785$ - 0,031 CAR - 0,121 NPL - 0,086LDR - 0,223 BOPO + 0,178 NIM

Nilai konstanta pada penelitian ini diperoleh nilai 27,785 yang dapat diartikan bahwa tanpa adanya perubahan dari variabel bebas atau variabel CAR, NPL, LDR, BOPO dan NIM maka profitabilitas pada Bank Perkreditan Rakyat mengalami peningkatan

Capital adequacy ratio (CAR) Bank Perkreditan Rakyat di Indonesia mempunyai dampak negatif terhadap profitabilitas bank dengan koefisien regresinya sebesar - 0,031. Ini dapat dijelaskan setiap adanya peningkatan Capital adequacy ratio $(C A R)$ atau semakin tinggi CAR maka profitabilitas pada Bank Perkreditan Rakyat di Indonesia akan mengalami penurunan, atau sebaliknya. Hipotesis diterima pada taraf signifikan $5 \%$, ini dibuktikan melalui nilai probabilitas (sig) sebesar 0,006 di mana nilai probabilitas tersebut di bawah 0,05 . 
Non Performing Loan (NPL) Bank Perkreditan Rakyat di Indonesia mempunyai pengaruh negatif terhadap profitabilitas bank dengan koefisien regresi sebesar - 0,121. Hal ini dapat diartikan setiap adanya peningkatan NPL atau semakin besar NPL maka profitabilitas pada Bank Perkreditan Rakyat di Indonesia akan mengalami penurunan, atau sebaliknya. Hipotesis2 ditolak, karena dibuktikan dengan nilai probabilitas (sig) sebesar 0,278 yang mana nilai tersebut masih di atas 0,05 .

Loan to deposit ratio (LDR) Bank Perkreditan Rakyat di Indonesia mempunyai pengaruh positif terhadap profitabilitas bank dengan koefisien regresi sebesar - 0,086. Hal ini dapat diartikan bahwa setiap peningkatan Loan to deposit ratio (LDR) maka profitabilitas pada Bank Perkreditan Rakyat di Indonesia mengalami penurunan. Hipotesis diterima, karena dibuktikan dengan nilai probabilitas (sig) sebesar 0,005 yang mana nilai tersebut dibawah 0,05 .

Biaya operasional dan pendapatan opoerasional (BOPO) Bank Perkreditan Rakyat di Indonesia mempunyai pengaruh negatif terhadap profitabilitas bank dengan koefisien regresi sebesar - 0,223. Hal ini dapat diartikan bahwa setiap peningkatan BOPO maka profitabilitas pada Bank Perkreditan Rakyat di Indonesia mengalami penurunan atau sebaliknya setiap penurunan BOPO akan meningkatkan profitabilitas. Hipotesis diterima, karena dibuktikan dengan nilai probabilitas (sig) sebesar 0,000 yang mana nilai tersebut dibawah 0,05 .

Net interest margin (NIM) Bank Perkreditan Rakyat di Indonesia mempunyai pengaruh positif terhadap profitabilitas bank dengan koefisien regresi sebesar 0,178. Hal ini dapat diartikan bahwa setiap peningkatan NIM maka profitabilitas pada Bank Perkreditan Rakyat di Indonesia mengalami peningkatan atau sebaliknya setiap penurunan NIM juga akan menurunkan profitabilitas. Hipotesis diterima, karena dibuktikan dengan nilai probabilitas (sig) sebesar 0,006 yang mana nilai tersebut dibawah 0,05 .

\section{Koefisien Determinasi}

Berdasarkan hasil perhitungan diperoleh nilai koefisien determinasi (Adjusted $R$ Square) sebesar 0,891. Hal ini berarti besar variasi variabel profitabilitas pada Bank Perkreditan Rakyat di Indonesia yang dapat diterangkan oleh variasi variabel CAR, NPL, LDR, BOPO dan NIM adalah sebesar 89,1\%, sedangkan sisanya sebesar 10,9\% dipengaruhi oleh variabel lain di luar model penelitian. 


\section{PEMBAHASAN}

\section{Pengaruh Capital Adequacy Ratioterhadap Profitabilitas Bank Perkreditan Rakyat}

Hasil penelitian menunjukkan bahwa capital adequacy ratio (CAR)Bank Perkreditan Rakyat di Indonesia mempunyai pengaruh negatif terhadap profitabilitas bankdengan koefisien regresi sebesar - 0,031. Hal ini dapat diartikan setiap adanya peningkatan Capital adequacy ratio (CAR) atau semakin besar CAR maka profitabilitas pada Bank Perkreditan Rakyat di Indonesia akan mengalami penurunan, atau sebaliknya.

Hasil penelitian ini sejalan dengan penelitian yang telah dilakukan Damayanti dan Savitri (2012), yaitu semakin meningkat capital adequacy ratio akan berdampak pada kondisi kecukupan modal dari perusahaan yang berlebihan, sehingga reputasi bank menjadi terjaga, tapi disisi lain ada dana yang menganggur. Dampak dari terjaganya reputasi akan meningkatkan kepercayaan masyarakat terhadap bank tersebut. Sehingga secara tidak langsung bank akan mendapatkan dana masuk yang semakin lebih besar, serta permintaan untuk mengajukan pembiayaan juga akan meningkat untuk yang sisi lainnya adalah terdapat dana yang tidak terserap secara maksimal.

\section{Pengaruh Non Performing Loan (NPL) terhadap Profitabilitas Bank Perkreditan}

\section{Rakyat}

Non Performing Loan (NPL) Bank Perkreditan Rakyat di Indonesia mempunyai pengaruh negatif signifikan terhadap profitabilitas Bank Perkreditan Rakyat di Indonesia bank dengan koefisien regresi sebesar - 0,121. Hal ini dapat diartikan setiap adanya peningkatan NPL atau semakin besar NPF maka profitabilitas pada Bank Perkreditan Rakyat di Indonesia akan mengalami penurunan.

Hasil penelitian ini sejalan dengan penelitian dari Wibowo dan Syaichu (2013) yang menunjukkan bahwa kondisi NPF yang lebih besar dalam satu periode tidak secara langsung memberikan penurunan laba pada periode yang sama. Dampak dari NPF terhadap ROA adalah berkaitan dengan penentuan tingkat pembiayaan bermasalah yang diberikan oleh sebuah bank. Di sisi lain adanya tingginya NPF dapat menghambat perputaran modal kerja dari bank. Bank yang memiliki jumlah 
pembiayaan bermasalah yang diluar dibatas ketentuan, memungkinkan bank terlebih dahulu mengevaluasi kinerjanya dengan sementara menghentikan penyaluran pembiayaannya hingga NPF berkurang.

Berdasarkan data yang ada NPF bank Bank Perkreditan Rakyat relatif kecil atau sedikit yang bermasalah.NPF yang ada di bank Bank Perkreditan Rakyat juga jauh dibawah ketentuan bank konvensional yaitu $5 \%$ sehingga NPF tidak mempengaruhi profitabilitas Bank Perkreditan Rakyat. Hasil yang sama ditunjukkan oleh penelitian Muliawati dan Khoirudin (2015) yang menyatakan bahwa NPL tidak berpengaruh terhadap ROA. Hal ini dapat dilihat dari nilai NPL relatif rendah, hal ini sangat dimungkinkan bahwa angka kredit bermasalah di bank umum juga rendah, sehingga NPL atau NPF tidak mempunyai dampak pada profitabilitas Bank Bank Perkreditan Rakyat di Indonesia.

Rendahnya NPL pada bank menunjukkan bank terlalu hati - hati dalam menyalurkan pembiayaan sehingga akan mengurangi pendapatan bank, demikian sebaliknya NPF yang tinggi menunjukkan keberanian bank dalam menyalurkan pembiayaan (Widyaningrum dan Septiarini, 2015). Hal ini menunjukkan bahwa tinggi dan rendahnya NPF tidak mempunyai dampak pada tingkat ROA dari bank tersebut.

\section{Pengaruh Loan to Deposit Ratio terhadap Profitabilitas Bank Perkreditan Rakyat}

Loan to deposit ratio (LDR) Bank Perkreditan Rakyatdi Indonesia mempunyai pengaruh negatif terhadap profitabilitas bank dengan koefisien regresi sebesar - 0,086. Hal ini dapat diartikan bahwa setiap peningkatan Loan to deposit ratio (LDR) maka profitabilitas pada Bank Perkreditan Rakyat di Indonesia mengalami peningkatan, pernyataan tersebut bermakna atau signifikan, yaitu setiap peningkatan $L D R$ akan menurunkan profitabilitas Bank Perkreditan Rakyat di Indonesia.

Hasil penelitian ini sejalan dengan penelitian dari Sudarmawati dan Pramono (2017). Hal ini menunjukkan bahwa loan to deposit ratio yang tinggi menunjukkan kredit yang diberikan kepada masyarkaat atau nasabah adalah lebih besar dari dana pihak ketiga yang diterima, hal ini berdampak pada kemungkinan peningkatan risiko dan dampaknya adalah justru akan menurunkan profitabilitas bank (Ali dan Laksono, 201\&)

\section{Pengaruh BOPO terhadap Profitabilitas Bank Perkreditan Rakyat}


Biaya operasional dan pendapatan opoerasional (BOPO) Bank Perkreditan Rakyat di Indonesia mempunyai dampak negatif terhadap profitabilitas bank dengan koefisien regresi sebesar - 0,223. Hal ini dapat diartikan bahwa setiap peningkatan BOPO maka profitabilitas pada Bank Perkreditan Rakyat di Indonesia mengalami penurunan atau sebaliknya setiap penurunan BOPO akan meningkatkan profitabilitas.

Hasil penelitian ini menunjukkan bahwa BOPO berpengaruh negatif dan bermakna terhadap ROA, karena nilai rasio BOPO tergolong rendah dapat meningkatkan laba bank. Peningkatan rasio BOPO maka itu sebagai akibat tingginya biaya dana yang dihimpun dan rendahnya pendapatan bunga dari penanaman dana sehingga pada akhirnya dapat menurunkan tingkat profitabilitas/ ROA (Defri, 2012). Penelitian ini sejalan dengan penelitian Martindes (2013) ; Khoirunisa (2016) yang menyatakan bahwa BOPO berpengaruh negatif dan signifikan terhadap ROA.

\section{Pengaruh Net Interest Margin (NIM) terhadap Profitabilitas Bank Perkreditan}

\section{Rakyat}

Net Interest Margin (NIM) Bank Perkreditan Rakyat di Indonesia mempunyai dampak positif terhadap profitabilitas bank dengan koefisien regresi sebesar 0,178. Hal ini dapat diartikan bahwa setiap peningkatan NIM maka profitabilitas pada Bank Perkreditan Rakyat di Indonesia mengalami peningkatan atau sebaliknya setiap penurunan NIM akan menurunkan profitabilitas.

Hasil penelitian ini menunjukkan bahwa NIM diperoleh dengan membandingkan pendapatan bersih bunga dengan aktiva produktif.NIM berpengaruh positif dan bermakna terhadap ROA, karena nilai rasio NIM tergolong tinggi dapat meningkatkan laba bank. Peningkatan rasio NIM pada akhirnya dapat meningkatkan tingkat profitabilitas/ ROA (Almilia dan Herdiningtyas, 2005). Penelitian ini sejalan dengan penelitian Ali dan Laksono (2017) yang menyatakan bahwa NIM berpengaruh positif dan signifikan terhadap ROA.

\section{PENUTUP}

\section{Implikasi Manajerial}

1. Kebutuhan pembiayaan bener - benar diperhatikan atau disesuaikan dengan dana pihak ketiga dari simpanan dan modal inti. Langkah ini dapat dilakukan dengan mengupdate pembiayaan yang telah dilakukan secara lebih cepat atau pendek (per 
minggu). Hal ini dimaksudkan agar dana pembiayaan dapat sejalan dengan diana pihak ketiga yang diterima.

2. Rasio kecukupan modal atau capital adequacy ratio sebaiknya pada posisi kisaran $8 \%$ (persyaratan BI). Kelebihan atau makin tinggi rasio kecukupan modal memberikan gambaran bahwa modal yang terlalu tinggi atau berlebihan dibanding dengan aktivanya. Demikian juga apabila rasio permodalan ini terlalu rendah akan mengganggu stabilitas bank. Bank sebaiknya selalu memonitor modal yang dibutuhkan agar rasio ini pada posisi yang aman dan efisien.

3. Bank Perkreditan Rakyat lebih hati - hati dalam memberikan pembiayaan kepada para debiturnya. Berbagai pembiayaan yang menjadi target lebih baik disalurkan pada kondisi yang dapat diterima (visible), sehingga bagian pembiayaan lebih hati - hati dan lebih profesional.

4. Kebutuhan operasional benar - benar disesuaikan dengan aktivitas yang ada. Pihak pengelola bank melakukan inventaris atau perhitungan secara lebih detail dan menyeluruh untuk mengetahui pos - pos atau kegiatan mana yang dirasa membutuhkan dana atau anggaran yang tinggi sehingga penghematan atau efisiensi dapat diwujudkan.

\section{Kelemahan Penelitian}

Beberapa keterbatasan penelitian yang dapat ditarik dari penelitian ini adalah sebagai berikut :

1. Hasil penelitian ini belum dapat digeneralisasi pada kasus lain diluar obyek penelitian yaitu pada kasus - kasus pada bank umum konvensional atau bank milik pemerintah. Pada sektor bank lainnya sangat berbeda dengan bank Bank Perkreditan Rakyat. Sehingga hasil ini sangat terbatas pada kasus - kasus yang sejenis.

2. Obyek penelitian masih membatasi pada sektor bank Bank Perkreditan Rakyat di Indonesia. Penelitian ini tidak memasukkan sektor bank yang lainnya di Indonesia.

\section{Agenda Mendatang}

Beberapa agenda penelitian mendatang yang dapat diberikan dari penelitian ini antara lain, adalah : 
1. Penelitian mendatang mengarahkan pada obyek penelitian yang lebih luas dengan mengambil obyek - obyek kantor bank yang terdapat unit usaha Bank Perkreditan Rakyat.

2. Menambah atau memasukkan variabel lain yang dapat meningkatkan pengaruh dan determinasi terhadap profitabilitas bank Bank Perkreditan Rakyat.

3. Membuat permodelan dengan variabel intervening ataupun variabel moderating.

\section{DAFTAR PUSTAKA}

Achmad, S. 2003. Ekonomi Perbankan. Jakarta: STIE Gunadarma.

Ahmad Buyung Nusantara. 2009. "Analisis Pengaruh NPL, CAR, LDR, dan BOPO Terhadap Profitabilitas Bank”. Tesis.Universitas Diponegoro.

Ali, Muhammad dan Laksono, Roosaleh., 2017., Pengaruh Net Interest Margin (NIM), Biaya Operasional Terhadap Pendapatan Operasional BOPO), Loan to Deposit Ratio (LDR) dan Non Performing Loan (NPL)Terhadap s (ROA)., Jurnal Riset Akuntansi Dan Keuangan, Vol 5 Nomor 2, Bandung.

Apsari. Idha Ayu., Dwiatmanto dan Devi Farah Azizah., 2015., Pengaruh Return On Equity. Net Profit Margin. Debt to Equity Ratio. dan Longterm Debt to Equity Ratio terhadap Price Book Value (Studi pada Perusahaan Sub Sektor Makanan dan Minuman yang Terdaftar di Bursa Efek Indonesia Periode Tahun 20102013)., Jurnal Administrasi Bisnis (JAB)|Vol. 27 No. 2 Oktober 2015

Astohar., 2013., Statistika Bisnis Kasus dan Solusi., Penerbit Duta Nusindo., Semarang.

Astohar., 2016., Pengaruh Capital Adequacy Ratio (Car) Dan Financing To Deposit Ratio Terhadap Profitabilitas Perbankan Bank Perkreditan Rakyat Di Indonesia Dengan Inflasi Sebagai Variabel Pemoderasi., Among Makarti Vol.9 No.18, Desember 2016

Bernardin, Deden Edwar Yokeu., 2016., Pengaruh CAR dan LDR terhadap Return on Assets, Ecodemica, Vol IV, No 2.

Dwi Indah Putrianingsih $\square$ Arief Yulianto., 2016, Pengaruh Non Performing Loan (NPL) dan Capital Adequacy Ratio (CAR) terhadap Profitabilitas., Management Analysis Journal 5 (2) (2016)

Dendawijaya, Lukman. 2005. Manajemen Perbankan. Jakarta: Ghalia Indonesia.

Dwijayanthy, Febrina dan Naomi, Prima., 2009., Analisis Pengaruh Inflasi, BI Rate, dan Nilai Tukar Mata Uang terhadap Profitabilitas Bank Periode 2003-2007., Karisma., Vol. 3 (2): 87-98, 2009

Defri., 2012., Pengaruh Capital Adequacy Ratio (CAR), Likuiditas Dan Efisiensi Operasional Terhadap Profitabilitas Perusahaan Perbankan Yang Terdaftar Di BEI., Jurnal Manajemen, Volume 01, Nomor 01, September 2012 
Fahmi, Irfam 2015, Manajemen Perbankan Konvensional \&Bank Perkreditan Rakyat, Penerbit Mitra Wacana Media, Jakarta.

Ghozali, Imam, 2007, Manajemen Risiko Perbankan Pendekatan VaR, Badan Penerbit Universitas Diponegoro, Semarang.

Ghozali. Imam., 2018., Aplikas Analisis Multivariate dengan Program IBM SPSS 25.,Edisi 9., Badan Penerbit Universitas Diponegoro., Semarang.

Halim \& Hanafi, 2016, Analisis Laporan Keuangan, Palangan Tentara Pelajar, Yogyakarta.

Husnan Suad dan Pudjiastuti., 2012.,Dasar - Dasar Manajemen Keuangan., UPP STIM YKPN., Edisi 6., Yogyakarta.

Hutagalung, Esther Novelina dkk. 2011. Analisis Rasio Keuangan Terhadap Kinerja Bank Umum di Indonesia. Jurnal Aplikasi Manajemen, (Online), Vol. 11, No. 1.

Indrayani, Putu Agustina et. al 2016, Pengaruh Non Perfoming Loan (NPL), Loan ToDeposit Ratio (LDR) Dan Net Interest Margin (NIM) Terhadap Return On Asset (ROA) PadaBank Umum Yang Terdaftar Di Bursa Efek Indonesia Tahun 2014, Jurnal, UniversitasPendidikan Ganesha.

Kasmir 2012, Manajemen Perbankan, Edisi Revisi, Rajawali Pers, Jakarta.

Khoirunnisa, Hani Maulida, Rodhiyah, Saryadi., 2016., Pengaruh Capital Adequacy Ratio (CAR), Loan To Deposit Ratio (LDR) dan BOPO terhadap Profitabilitas (ROA dan ROE) Bank Persero Indonesia yang Dipublikasikan Bank Indonesia Periode 2010 - 2015., Jurnal Administrasi Bisnis., Semarang.

Latifah, Nurul Maulidya, Rodhiyah, Saryadi. 2012, Pengaruh Capital Adequacy Ratio (CAR), Non Performing Loan (NPL) dan Loan to Deposit Ratio (LDR) terhadap (ROA) (Studi kasus pada Bank Umum Swasta Nasional Devisa Go Public di Bursa Efek Indonesia Periode 2009-2010)., Jurnal Ilmu Administrasi Bisnis., Semarang.

Matindas, Anggria Maya., Pangemanan, Sifrid S. dan David P.E. Saerang., 2013., Pengaruh Capital Adequacy Ratio (CAR), BOPO dan Non Performing Loan (NPL) terhadap Kinerja Keuangan Perbankan di Indonesia., Jurnal Unsrat.

Moslem, Orchidia Seta dan M. Chabachib., 2016., Analisis Faktor-Faktor Yang Berpengaruh Terhadap Profitabilitas Perbankan (Studi Perbandingan Bank Devisa dan Bank Non Devisa Di Indonesia Periode 2010-2014), Jurnal Bisnis dan Manajemen., Vol 4 no 4

Mudrajad Kuncoro dan Suhardjono. 2002. Manajemen Perbankan Teori dan Aplikasi. Yogyakarta; BPFE UGM.

Olarewaju, Odunayo M. dan Adeyemi., 2015, Oluwafeyisayo K., Causal Relationship between Liquidity and Profitability of Nigerian Deposit Money Banks., International Journal of Academic Research in Accounting, Finance and Management Sciences., Vol 5, No.2

Pranata, A.A Alit Wahyu Dwi., 2015., Pengaruh Capital Adequacy Ratio, Loan To Deposit Ratio dan Ukuran Perusahaan pada Profitabilitas Bank di Bursa Efek Indonesia., E-jurnal Akuntansi Universitas Udayana 11.1 
Rahmani, Nur Ahmadi Bi., 2017., Analisis Pengaruh Capital Adequacy Ratio (CAR) dan Financing to Deposit Ratio (FDR) terhadap (ROA) dan Return On Equity (ROE) Pada Perusahaan Bank Bank Perkreditan Rakyat di Indonesia., Jurnal Human Falah., Vol 4 Nomor 4. Yogyakarta.

Riyadi, Slamet ., 2006., Banking Assets and Liability Management., Lembaga Penerbit FE UI, Jakarta

Rivai, Veitzal et. al 2013, Credit Manajemen Handbook, Raja Grafindo Persada, Jakarta.

Samsara, Essamaski., 2016., Analisis Pengaruh Capital Adequacy Ratio (CAR), non performing Loan (NPL) dan Loan to Deposit Ratio (LDR) terhadap Return on Asset (ROA) pada kelompok Bank Pembangunan Daerah dan Bank Non Devisa di Indonesia., Indonesia Banking School.

Simanjuntak, Jontro., 2016., Pengaruh Capital Adequacy Ratio (CAR), Loan to Deposit Ratio (LDR) dan Non Performing Loan (NPL) Terhadap $s$ (ROA) Pada Sektor Perbankan di Bursa Efek Indonesia., Jurnal Bisnis dan Manajemen Vol 2 Nomor 2.

Simorangkir, O.P. (2004). Pengantar Lembaga Keuangan Bank dan non Bank. Jakarta: Ghalia Indonesia.

Sudarmawanti, Erna dan Pramono, Joko, 2017., Pengaruh CAR, NPL, BOPO, NIM dan LDR terhadap ROA (Studi kasus pada Bank Perkreditan Rakyat di Salatiga yang terdaftar di Otoritas Jasa Keuangan Tahun 2011-2015)., AmongMakarti., Vol 10 No 19.

Sudarmanta, I Ketut 2016, Determinasi Profitabilitas Sektor Perbankan Di Bursa Efek Indonesia, Pascasarjana Universitas Warmadewa, Denpasar, Diakses 22 Agustus 2017, dari www.ejournal.warmadewa.ac.id

Veithzal Rivai, Andria Permata Veithzal dan Ferry N. Idroes. 2007. Bank and Financial Institution Mangement. Jakarta : PT. Raja Grafindo Persada. 